\title{
Pendampingan Kelompok Petani Muda dalam Upaya Menggali Potensi dan Kreativitas Desa Pada Masa Pandemi di Desa Sumberejo Kota Batu
}

(Assistance of Young Farmer Groups in Efforts to Explore Village Potential and Creativity During the Pandemic Period in Sumberejo Village, Batu City)

\author{
Farah Mutiara ${ }^{1}$, Eri Yusnita Arvianti ${ }^{2 *}$, A. Yusuf Kholil ${ }^{3}$ \\ ${ }^{1,2,3}$ Program Studi Agribisnis, Fakultas Pertanian, Universitas Tribhuwana Tunggadewi Malag
}

\section{ARTICLE INFO}

\section{Article history}

Received : 11 July 2021

Revised : 21 November 2021

Accepted : 03 December 2021

DOI :

https://doi.org/10.33366/jast.v5i2 .2590

Keywords :

creativity; potential;

role; youth

*e-mail corresponding author : yusnitaarvianti@gmail.com

\section{ABSTRAK}

WHO (World Health Organization) menetapkan virus corona sebagai pandemi global. Indonesia sebagai salah satu negara yang terpapar dan adanya pandemi tersebut telah merubah kehidupan seluruh kalangan masyarakat dari berbagai lapisan. Diharapkan generasi muda sebagai sosok yang muda, dinamis, penuh energi, penuh optimis dapat membawa perubahan yang bergerak dan berusaha untuk membantu pemerintah dalam memutus penyebaran covid-19. Salah satunya yaitu peran pemuda di sektor pertanian. Metode pelaksanaan yang dipakai untuk menggali potensi dan kreativitas petani muda di Desa Sumberejo yaitu dengan memberikan penyuluhan. Kegiatan yang dilakukan yaitu dengan memberikan pengenalan teknologi IT, pelatihan dan penyuluhan pemasaran dan pembukuan usaha yang lebih modern kepada pemuda. Adanya kegiatan tersebut sangat cocok untuk kondisi pembatasan sosial masyarakat saat ini sedang dijalankan.Tujuan kegiatan ini yaitu dapat memberikan pengetahuan kepada petani muda di Desa Sumberejo sehingga pengetahuan dan keterampilan petani muda dapat meningkat dalam pembukuan usaha berbasis internet, meningkatkan kreativitas dalam pemasaran online sehingga mereka lebih termotivasi dan pandai membaca peluang dan meningkatkan kreativitas pemuda desa di masa pandemi. covid-19 dan adanya pembatasan sosial tidak akan menyurutkan usaha mereka di bidang usaha sayuran organik.
\end{abstract}

\section{PENERBIT}

\section{UNITRI PRESS}

Jl. Telagawarna, TlogomasMalang, 65144, Telp/Fax: $0341-565500$

\section{cc) (†) (อ)}

This is an open access article under the Creative Commons Attribution-ShareAlike $\quad \mathbf{4 . 0}$ International License. Any further distribution of this work must maintain attribution to the author(s) and the title of the work, journal citation and DOI. CC-BY-SA

Cara Mengutip : Mutiara, F., Arvianti, E.Y., Kholil, A.Y. (2021). Pendampingan Kelompok Petani Muda dalam Upaya Menggali Potensi dan Kreativitas Desa Pada Masa Pandemi di Desa Sumberejo Kota Batu. JAST: Jurnal Aplikasi Sains dan Teknologi, 5(2), 76-83. doi: https://doi.org/10.33366/jast.v5i2.2590 


\section{PENDAHULUAN}

Indonesia sudah menerapkan kebijakan Pembatasan Sosial Berskala Besar di beberapa daerah yang padat penduduk [1]. Masyarakat yang tidak mematuhi peraturan Pembatasan Sosial Berskala Besar masih banyak dan dinilai menjadi salah satu penyebab permasalahan pandemi yang tidak segera berakhir. Semua warga negara Indonesia, khusunya generasi muda mempunyai peran dan tugas untuk membantu menghadapi Covid19. Generasi muda diharapkan dapat menjadi agent of change, sebagai sosok dinamis, penuh energi, penuh optimis untuk membantu pemerintah memutuskan rantai penyebaran covid-19 dan bangkit lagi dari keterpurukan ekonomi. Pandemi covid-19 menjadi salah satu yang menimbulkan ketidakstabilan ekonomi pada suatu negara bahkan secara global (Khairad, 2020; Soleh et al., 2020).

Pada masa pandemi Covid-19 tidak mudah untuk bertahan dalam dunia usaha namun bukan hal yang sangat mustahil jika dapat bertahan. Produk yang inovatif dan kreatif yang diciptakan dapat menjadikan produk yang memiliki keunikan dan keunggulan sehingga produk tersebut dapat bertahan di tengah persaingan pasar. Peluang usaha berbasis kreativitas harus terus dimunculkan seperti adanya unsur usaha berbasis internet sebagai alat komunikasi yang sangat efektif untuk dikembangkan sebagai ekonomi pinggiran di desa [4]. Banyak tantangan yang perlu dihadapi karena mengembangkan ide bisnis kreatif tidak mudah dan terkadang dianggap tidak biasa oleh masyarakat. Oleh karena itu dibutuhkan komitmen untuk mengembangkan jenis usaha tersebut. Salah satu usaha yang dikembangkan di Desa Sumberejo saat ini adalah usaha sayuran organik dengan berbagai kemasan dan melalui jarngan pemasaran online.

Saat ini pertanian organik sedang berkembang pesat karena banyak masyarakat yang sadar akan pentingnya makanan yang sehat tanpa mengandung bahan kimia bagi tubuh. Pertanian organik merupakan jawaban atas revolusi hijau akibat pemakaian pupuk dan pestisida kimia yang tidak terkendali sehingga menyebabkan tanah menjadi tidak subur serta menyebakan kerusakan lingkungan [5]. Konsep pertanian organik sudah dibangun di tengah masyarakan yaitu pertanian organik merupakan penghasil makanan sehat. Selain itu pertanian oeganik merupakan pertanian berkelanjutan yang sangat perlu partisipatif dari petani untuk mengembangkan penelitian terkait pertanian organik [6].

Saat ini banyak yang sudah melakukan budidaya pertanian secara organik termasuk usaha tani brokoli organik yang dari tahun ke tahun tambah meningkat yang dikarenakan sudah banyak peminat di seluruh daerah. Salah satunya adalah sayuran organik yang sangat digemari oleh masyarakat. Brokoli organik merupakan salah satu jenis sayuran organik yang banyak dibudidayakan. Perkembangan produksi brokoli organik dari tahun ke tahun cenderung meningkat. Usaha tani brokoli organik memerlukan jumlah tenaga kerja yang banyak mengingat budidaya organik membutuhkan tenaga kerja yang intensif dalam perawatan terutama dalam pengendalian hama yang mengandalkan pengendalian secara mekanik atau manual. Di Desa Sumberejo, usaha tani brokoli organik masih sangat sedikit peminatnya karena banyak petani yang berminat ke usaha tani non organik atau 
usaha tani yang menggunakan pupuk pestisida. Menurut para petani di desa tersebut, lebih banyak keuntungan jika mereka menekuni usaha tani dengan menggunakan pestisida kimia. Sehingga, sampai saat ini sebagian besar petani menekuni usaha tani dengan menggunakan pupuk pestisida kimia. Baru satu kelompok tani yang menekuni usaha tani secara organik tanpa menggunakan pupuk kimia atau merek. Mereka menggunakan pupuk organik yang diolah oleh masyarakat tersebut yang sudah bergabung dalam Pertanian Organik Kota Batu atau yang sering di kenal dengan PORKAB. Pemanfaatan pupuk kimia sebagai salah satu unsur dalam peningkatan kesuburan tanaman memberikan gambaran yang kurang mendukung keberlanjutan penggunaan lahan pertanian dalam jangka waktu yang panjang [7]. Penggunaan nutrisi organik dan biologis, pergantian tanaman, pengelolaan hama terpadu, serta peningkatan keberagaman hayati merupakan hal yang penting bagi praktik pertanian berkelanjutan [8].

Dengan ditunjang oleh potensi sumberdaya alam yang mendukung, maka para petani muda Sumberejo harus bisa membaca peluang bisnis dari sayuran organik ini. Oleh karena itu perlu dilakukan identifikasi masalah mengenai bagaimana pengetahuan dan motivasi anggota elompok petani muda Desa Sumberejo dalam upaya membuka peluang usaha baru di masa pandemi, bagaimana keterampilan anggota kelompok petani muda Desa Sumberejo dalam pembukuan dan bagaimana pengetahuan dan keterampilan bidang pemasaran pada anggota kelompok petani muda Desa Sumberejo sehingga pada pengabdian ini akan diberikan penyuluhan mengenai manajemen usaha pertanian dan pemasaran pada kelompok petani muda di Desa Sumberejo.

\section{METODE KEGIATAN}

Kegiatan Pengabdian Masyarakat ini dilaksanakan di desa Sumberejo, Batu dengan waktu pelaksanaan kegiatan adalah tiga bulan yaitu mulai Januari 2021 sampai dengan Maret 2021. Pelaksana kegiatan adalah tim kerja Pengabdian Masyarakat yang terdiri dari tiga dosen degan berbeda minat studi, yaitu Farah Mutiara dengan bidang studi pemasaran, Eri Yusnita Arvianti dengan bidang keahlian Manajemen Usaha Pertanian dan A. Yusuf Kholil dengan bidang studi penyuluhan serta 2 orang mahasiswa yaitu Daniel Simo dan Stephen. Mitra dalam kegiatan yang akan dibantu dalam pengentasan masalah dan pengembangan usaha adalah Petani Muda Organik di masa pandemi pimpinan Bapak Marsaji. Kegiatan dilaksanakan di lokasi mitra dalam bentuk penyuluhan dan sosialisasi yang tetap memegang teguh prinsip protokol kesehatan, keselamatan, dan 3M.

\section{KARYA UTAMA}

Pada masa pandemi covid-19 diperlukan beberapa aktifitas yang difokuskan untuk memfasilitasi peningkatan pendapatan petani salah satunya yaitu melalui pemberdayaan pemuda desa dengan pemanfaatan karang taruna dan kelompok pemuda desa sayuran organik, penyuluhan pembukuan usaha atau akuntansi agar pencatatan keuangan lebih 
tertata, penyuluhan manajemen usaha pertanian, serta penyuluhan pemasaran menggunakan alat konumikasi digital secara online dalam rangka peningkatan kreativitas pemuda desa di masa pandemi covid-19. Pemberdayaan sangat penting untuk penguatan suatu kelompok [9]. Untuk mencapai tujuan tersebut, dijabarkan lebih lanjut beberapa subprogram, diantaranya adalah penyuluhan manajemen usaha, penerangan tentang pembukuan secara lebih terperinci dan detail melalui pelatihan pembukan arus kas keluar masuk, laporan perubahan modal dan laporan rugi laba usaha tiap akhir bulan serta pemanfaatan IT small data yang lebih terintegrasi untuk pembuatan laporan keuangan usaha.

Program selanjutnya adalah penyuluhan pemasaran secara online, sehingga pembeli tidak perlu datang ke tempat usaha. Melalui pemasaran online pembeli tinggal memesan lewat internet dan barang akan dikirim tepat waktu sehingga berapa harga dan kapan pesanan datang bisa terlihat di program. Juga jumlah sayuran organik yang terjual juga bisa diketahui oleh produsen Sumberejo. Mengingat di masa pandemi interaksi sosial lebih dibatasi sehingga kreativitas pemasaran sangat diperlukan. Selain itu pemanfaatan internet juga meningkatkan nilai jual sehingga akan meningkatkan pendapatan [10]. Menurut Wirapraja \& Aribowo (2018), e-commerce dapat berperan aktif dalam menjaga tingkat permintaan terhadap produk, mengurangi biaya promosi, memperluas jangkauan pasar pada tingkatan pasar yang baru dan dapat memutus jalur distribusi.

Program pendampingan dan pembimbingan teknis dilaksanakan pada mitra secara sinergis dan bersama-sama antara tim abdimas UNITRI dan petani muda Sumberejo. Seorang petani diharapkan memiliki kompetensi yang bertujuan untuk mencapai target yang diinginkan melalui perencanaan [12]. Dibutuhkan perubahan keadaan masyarakat tradisional menjadi masyarakat moder untuk mengikuti perkembangan jaman [13]. Persoalan utama yang dihadapi petani muda yaitu metode pemasaran online yang masih kurang perlu ditingkatkan serta kemampuan membuat laporan keuangan yang belum jelas sehingga tidak tahu untung ruginya dari usaha sayuran organik. Berdasarkan survey pendahuluan didapatkan kesepakatan antara tim dengan mitra mengenai pemecahan permasalahan. Alternatif solusi yang akan dilakukan meliputi :

1. Pemaparan mengenai motivasi untuk bertahan di masa pandemi dengan membuka peluang usaha sampingan yang masih berbasis komoditi sayuran bisa dilakukan oleh pemuda desa dalam rangka menggali potensi sayuran organik di daerah Sumberejo.

2. Penyuluhan dan pendampingan pembukuan usaha berbasis internet dan online.

3. Pendampingan dan evaluasi setelah menggunakan pengenalan pembukuan usaha dan pemasaran online dengan basis IT. Hal ini akan mengubah sikap petani muda sehingga bisa lebih termotivasi untuk pandai-pandai membaca peluang dan meningkatkan kreativitas pemuda desa di masa pandemi. 


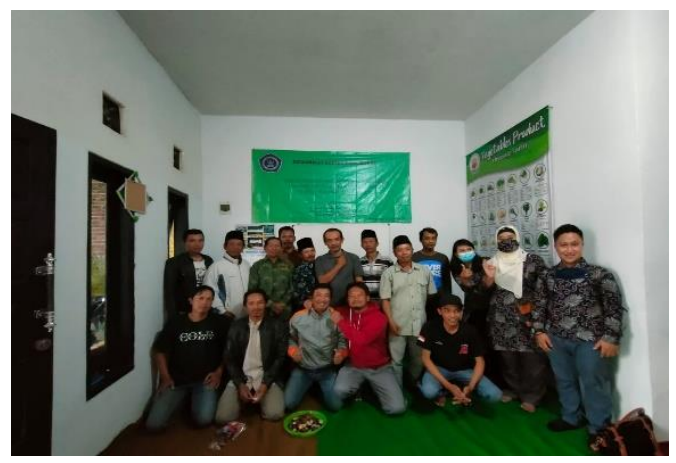

Gambar 1. Tim Abdimas UNITRI bersama dengan Kelompok Petani Muda Organik Sumberejo

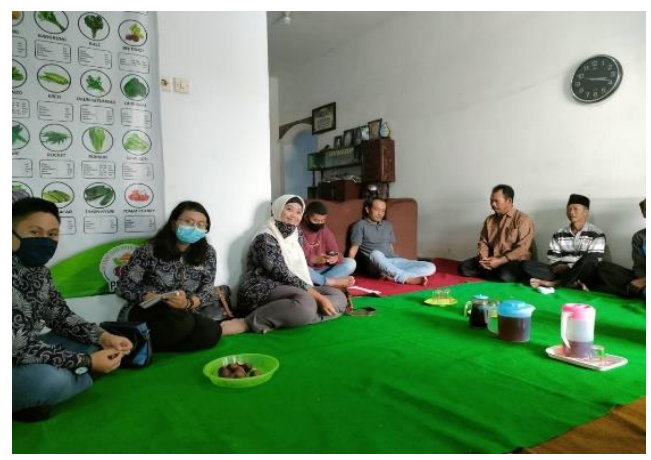

Gambar 2. Penyuluhan Pembukuan Usaha Berbasis Internet dan Online

\section{ULASAN KARYA}

Sebelum dilakukan penyuluhan dan pendampingan, tim Abdimas menanyakan terlebih dahulu keadaan kelompok petani muda tersebut terkait dengan pemasaran.Tempat yang digunakan untuk melakukan transaksi pembelian Kelompok Petani Organik Kota Batu adalah di jalan indragiri No 12, Rt 07, Rw 03, belakang balai Desa sumberejo. Pos pembelian juga berfungsi sebagai tempat penyetoran sayuran organik oleh para petani demi memenuhi permintaan dari para konsumen atau orang yang sudah melakukan kerja sama dengan Petani Organik Kota Batu. Tugas dari pos pembelian sebagai berikut :

- Menyusun pesanan dan membuat daftar permintaan untuk memesan bahan, barang, dan persediaan sayuran yang dipesan oleh konsumen.

- Mengirim pesanan kepada supplier

- Meninjau stok dan pesanan sesuai kebutuhan.

- Menjaga hubungan dengan supplier

Selain pos pembelian ada juga pos penjualan yang menghitung seluruh jumlah harga yang di beli konsumen dan memberikan pilihan bagi pembeli untuk melakukan pembayaran serta mengeluarkan tanda transaksi pembelian yang biasa disebut struk. Untuk konsumen sendiri yang sering order sayuran organik tersebut ada dari Surabaya atas nama ibu Diani, dari Kaliandra yang ada di Pasuruan, dari Tumpang, dari Mojokerto dan 
sebagian besar adalah penduduk dari kota batu itu sendiri. Tugas dari Pos Penjualan adalah sebagai berikut :

- Menangani permintaan pelanggan.

- Mencapai target penjualan harian.

- Mempertahankan hubungan pelanggan yang baik.

- Menjawab permintaan pelanggan melalui telepon.

- Membuat laporan.

- Mengembangkan bisnis.

Saluran (channel) pemasaran yang tepat sangat dibutuhkan dimasa pandemi ini di Sumberejo diantaranya dengan memperkenalkan upaya pemasaran online karena sayuran merupakan komoditi yang tidak bertahan lama dan harus dijual secepat mungkin. Tingkat harga atau bagian yang harus diterima oleh petani menjadi faktor utama yang sangat diperlukan guna mendapatkan keuntungan yang sebesar-besarnya. Pemasaran online bertujuan untuk menjangkau pelanggan lebih luas [14], [15].

Tanggapan petani muda terhadap kegiatan ini sangat baik dan mengucapkan terima kasih kepada Universitas Tribhuwana Tunggadewi karena memberikan penyuluhan dan pendampingan kepada kelompok petani muda meskipun kegiatan ini hanya dilakukan beberapa kali tatap muka. Pelaksanaan waktu kegiatan yang terbatas karena adanya Pembatasan Sosial Berskala Besar (PSBB) pada masa pandemi. Harapannya pendampingan yang dilakukan oleh Universitas Tribhuwana Tunggadewi dapat terus berlanjut.

\section{DAMPAK DAN MANFAAT KEGIATAN}

Adanya kegiatan ini memberikan dampak dan manfaat yang baik bagi kelompok petani muda di Desa Sumberejo. Petani muda mendapatkan motivasi untuk bertahan di masa pandemi dengan membuka peluang usaha sampingan yang masih berbasis komoditi sayuran sehingga dapat menggali potensi sayuran organik di daerah Sumberejo. Setiap petani muda yang hadir selama kegiatan siap dan bersemangat untuk mencoba usaha sampingan sayuran di masa pandemi. Selain itu terdapat peningkatan pengetahuan dan keterampilan petani muda dalam pembukuan usaha berbasis internet yang memanfaatkan aplikasi (misal: bukukas) dan penggunaan manual (misal menggunakan MS Excel) sehingga petani muda dapat memiliki pembukuan usaha yang terdokumentasi yang bermanfaat untuk pengembangan usaha. Dalam bidang pemasaran, petani muda mendapatkan ilmu sehingga meningkatankan kreativitas mereka dalam pemasaran yang semula sederhana dan konvensional yaitu dengan menunggu pembeli datang langsung menjadi pemasaran online yang memanfaatkan media sosial (misal: instagram, facebook) dan e-commerce (misal: tokopedia, shopee). Pengetahuan-pengetahuan yang didapatkan petani muda selama kegiatan mengubah sikap petani muda sehingga mereka lebih termotivasi dan pandai membaca peluang dan meningkatkan kreativitas pemuda desa di masa pandemi. covid-19. 


\section{KESIMPULAN}

Pemasaran menjadi suatu hal yang harus dipecahkan di Desa Sumberejo, hal ini dikarenakan pemasaran di sebagian petani Sumberejo masih bersifat sederhana belum mengenal pemasaran online seperti e-marketing. Pengetahuan dan keterampilan petani muda dalam pembukuan usaha berbasis internet, pemasaran online mengalami peningkatan sehingga mereka lebih termotivasi dan pandai membaca peluang untuk meningkatkan kreativitas dalam usaha mereka di bidang usaha sayuran organik pada masa pandemi covid-19. Selain itu pupuk bersubsidi di tengah pandemi yang berkepanjangan ini masih sangat dibutuhkan oleh sebagian besar petani muda Sumberejo. Diperlukan kerjasama yang sinergis antar semua pihak supaya kegiatan kreativitas berbasis sayuran organik terus bisa dilanjutkan dalam rangka ketahanan pangan. Harapan ke depan menjadi cita-cita para petani muda yaitu dapat membuka peluang usaha petik sayur di desa Sumberejo.

\section{UCAPAN TERIMA KASIH}

Kami ucapan terima kasih kepada Rektor, Dewan Pembina dan Pengawas Yayasan, LPPM, FORKAB Sumberejo, dan Tim Abdimas Universitas Tribhuwana Tungga Dewi.

\section{DAFTAR PUSTAKA}

[1] N. K. Wardhani, "Penerapan Kebijakan Pembatasan Sosial Berskala Besar di Indonesia dalam Prespektif Hukum dan HAM," KELUWIH J. Sos. dan Hum., vol. 2, no. 1, pp. 34-38, 2021, doi: 10.24123/soshum.v2i1.3990.

[2] F. Khairad, "Sektor Pertanian di Tengah Pandemi COVID-19 ditinjau Dari Aspek Agribisnis,” Jounal Agriuma, vol. 2, no. 2, pp. 82-89, 2020, [Online]. Available: http://www.ojs.uma.ac.id/index.php/agriuma/article/view/4357.

[3] A. N. Soleh, B. Krisbiyanti, J. A. Fahira, and T. Wulandari, "Upaya pemanfaatan lahan pekarangan rumah untuk budidaya tanaman sayuran sebagai penyedia pangan di masa pandemi Covid-19 di Desa Panjunan RT012 RW 002, Kec. Petarukan, Kab. Pemalang," Univ. Negeri Semarang, pp. 1-5, 2020.

[4] P. S. Prasetyo, T. Gunawan, T. Rachmawati, T. S. Herwanto, and ..., "Inovasi untuk mewujudkan desa unggul dan berkelanjutan," 2017, [Online]. Available: http://repository.unpar.ac.id/bitstream/handle/123456789/5722/Pius_143180\%28Ed $.2 \% 29-$ p.pdf? sequence $=4 \&$ isAllowed $=\mathrm{y}$.

[5] H. Mayrowani, "Pengembangan Pertanian Organik Di Indonesia The Development Of Organic Agriculture In Indonesia," Forum Penelit. Agro Ekon., vol. 30, no. 2, pp. 91-108, 2012.

[6] W. Artini, "Kebutuhan petani untuk penngembangan usahatani padi organik (Studi Kasus Terhadap Kelompok Petani Padi Organik di Kabupaten Kediri),” J. Agrinika, 
vol. 1, no. 1, pp. 12-26, 2016.

[7] E. Hamka et al., "Sistem Organik Untuk Pengembangan Pertanian Organik Di," J. Dedik., vol. Mei, pp. 62-70, 2018.

[8] F. Imani, A. Charina, T. Karyani, and G. W. Mukti, "Penerapan Sistem Pertanian Organik Di Kelompok Tani Mekar Tani Jaya Desa Cibodas Kabupaten Bandung Barat," Mimb. AGRIBISNIS J. Pemikir. Masy. Ilm. Berwawasan Agribisnis, vol. 4, no. 2, p. 139, 2018, doi: 10.25157/ma.v4i2.1173.

[9] A. O. Nazaruddin, "Pengaruh Penguatan Kelompok Tani Terhadap Partisipasi dan Motivasi Pemuda Tani Pada Usaha Pertanian di Leuwiliang, Bogor," J. Agribisnis Terpadu, pp. 1-14, 2017.

[10] B. Trymastuty, H. R. Alfannisa, and F. E. Dianastiti, "Pemasaran Produk Hasil Pertanian Desa Pasuruhan Kecamatan Mertoyudan Melalui Media Sosial: Strategi Pendampingan Terstruktur," ABDIPRAJA (Jurnal Pengabdi. Kpd. Masyarakat), vol. 1, no. 1, p. 116, 2020, doi: 10.31002/abdipraja.v1i1.3148.

[11] A. Wirapraja and H. Aribowo, "Pemanfaatan E-Commerce Sebagai Solusi Inovasi Dalam Menjaga Sustainability Bisnis," Teknika, vol. 7, no. 1, pp. 66-72, 2018, doi: 10.34148/teknika.v7i1.86.

[12] R. H. Rachmadian et al., "Kajian karakteristik petani dan potensi pemanfaatan lahan pertanian hortikultura Desa Sumber Brantas Kota Batu," J. Integr. dan Harmon. Inov. Ilmu-Ilmu Sos., vol. 1, no. 6, pp. 792-802, 2021, doi: 10.17977/um063v1i62021p792-802.

[13] S. Konyep, "Mempersiapkan Petani Muda dalam Mencapai Kedaulatan Pangan," J. Trit., vol. 12, no. 1, pp. 78-88, 2021, [Online]. Available: file:///E:/download/157Article Text-1035-1-10-20210621.pdf.

[14] N. Anggraini, Sutarni, C. Fatih, M. Zaini, Analianasari, and E. Humaidi, "Digital Marketing Produk Pertanian di Desa Sukawaringin Kecamatan Bangunrejo Kabupaten Lampung Tengah," J. Pengabdi. Nas., vol. 1, no. 1, pp. 36-45, 2020.

[15] N. O. Amir and D. Mustika, "Penerapan digital marketing dalam meningkatkan pendapatan pedagang bunga di Desa Sidomulyo Kota Batu," J. Ekon. Pertan. dan Agribisnis, vol. 3, no. 4, pp. 618-688, 2019, doi: 10.1007/978-3-030-13895-0_6-1. 